\title{
Studi Komparatif Ekuitas Merek Produk Buatan Malaysia dan Indonesia
}

\author{
Erna Listiana* \\ Universitas Tanjungpura
}

\begin{abstract}
The purpose of this study is to assess and obtain empirical evidence by testing different response towards brand equity products made in Indonesia and Malaysia. The observed product is processed food products biscuit, considering the existence of this Malaysia's processed food product has a close competition with domestic processed food products. Non-probability sampling technique in the form of purposive sampling is applied. The study was conducted on 160 respondents, consist of 80 consumers of biscuit brand made in Malaysia and 80 consumers of biscuit brand made in Indonesia. The study results that among Malaysia and Indonesia biscuit brand there is a difference in case of brand association, brand loyalty and brand quality as a whole, whereas the similarity between both products is in the perceived quality.
\end{abstract}

Keywords : Brand Equity, Brand Association, Perceived Quality, Brand Loyalty

\section{PENDAHULUAN}

Pilihan konsumen terhadap produk seringkali dengan mempertimbangkan merek dari produk tersebut, apalagi kalau merek tersebut sudah memiliki posisi yang kuat di pasar sasarannya, konsumen semakin menjadikannya sebagai pertimbangan utama dalam keputusan pembelian mereka. Dalam menghadapi persaingan yang ketat, merek yang kuat merupakan suatu pembeda yang jelas, bernilai, dan berkesinambungan, yang menjadi ujung tombak bagi daya saing perusahaan dan sangat membantu dalam strategi pemasaran. Menurut Kotler \& Keller (2012), merek yang kuat menciptakan kepercayaan dan kenyamanan yang lebih besar, serta menciptakan citra akan kualitas yang lebih baik. Merek yang kuat dapat menambah nilai dari barang atau jasa yang dijual yang dapat diketahui dari respon positif konsumen terhadapnya, inilah yang dikenal sebagai ekuitas merek.

Aaker (1991) mengemukakan bahwa ekuitas merek adalah seperangkat asset dan liabilitas merek yang berkaitan dengan suatu merek, nama dan simbolnya, yang menambah atau mengurangi nilai yang diberikan oleh sebuah barang atau jasa kepada perusahaan atau para pelanggan perusahaan. Dari definisi ini, selanjutnya Keller (1993)

\footnotetext{
* Korespondensi : Erna Listiana, Jurusan Manajemen, Fakultas Ekonomi, Universitas Tanjungpura, Jalan Hadari Nawawi, Pontianak 78124, Indonesia. Email: erlistiana@ yahoo.co.id
} 
mengemukakan bahwa ekuitas merek dari perspektif individu pelanggan disebut ekuitas merek berbasis pelanggan. Ekuitas merek berbasis pelanggan terjadi ketika pelanggan memberikan respon berbeda terhadap tindakan pemasaran, dimana perbedaan respon tersebut terjadi karena adanya perbedaan pengetahuan pelanggan tentang merek. Dengan demikian, ekuitas merek dalam hal ini terjadi ketika pelanggan mengenali merek dan menanggapi merek dengan asosiasi yang menyenangkan, kuat dan unik dalam memorinya. Perbedaan respon pelanggan terhadap pemasaran merek yang tampak pada pengetahuannya tentang merek inilah yang dikenal sebagai ekuitas merek berbasis pelanggan (Keller, 1993).

Sejumlah manfaat akan dihasilkan dari ekuitas merek, diantaranya adalah memperoleh loyalitas pelanggan yang lebih besar, mampu menghadapi persaingan, mampu menghadapi krisis pemasaran, memperoleh margin harga yang lebih tinggi, respon pelanggan yang lebih inelastis terhadap kenaikan harga, meningkatkan komunikasi pemasaran yang efektif, kemungkinan peluang lisensi dan menambah peluang untuk perluasan merek (Keller, 2008). Dengan demikian membangun, mempertahankan dan meningkatkan ekuitas merek merupakan upaya yang harus dilakukan dan tidak bisa ditawar lagi apalagi dalam kondisi persaingan yang terjadi saat ini. Merek yang sudah memiliki ekuitas akan mampu menambah nilai bagi produk atau pelayanan, sehingga membuahkan tambahan bagi kepuasan pelanggan, yang selanjutnya dapat memberikan sejumlah manfaat besar bagi perusahaan seperti meningkatnya penjualan, loyalias pelanggan dan keuntuangan.

Ekuitas merek menurut Aaker (1991) terdiri dari lima dimensi yang berbeda, meliputi kesadaran merek, asosiasi merek, kualitas yang dirasakan dan loyalitas merek, serta aset merek lainnya. Kesadaran merek, asosiasi merek, kualitas yang dirasakan dan loyalitas merek mewakili persepsi dan reaksi konsumen terhadap merek. Lebih lanjut Aaker (1991) mengemukakan bahwa kesadaran merek adalah kemampuan calon pembeli untuk mengenali atau mengingat bahwa merek merupakan anggota kategori produk tertentu, sedangkan asosiasi merek adalah segala sesuatu yang terkait tentang sebuah merek dalam memori konsumen.

Asosiasi merek dapat mencerminkan fitur produk atau aspek lainnya dari merek yang bersangkutan (Chen, 2001). Kualitas yang dirasakan merupakan penilaian pelanggan atas atribut dan keunggulan suatu produk (Zeithaml, 1988 dalam Aaker, 1991). Loyalitas merek menunjukkan kesetiaan pelanggan pada merek tertentu dengan komitmen yang tinggi dan berniat untuk terus membelinya dimasa mendatang saat ia membutuhkannya (Mowen \& Minor, 2001).

Arti penting ekuitas merek semakin dirasakan apalagi dalam kondisi persaingan yang semakin ketat. Pesaing tidak hanya berasal dari pemasar lokal di dalam negeri namun juga pemasar asing, dimana saat ini semakin banyak serbuan merek asing dalam pasar domestik. Ketatnya persaingan diantara merek domestik dan asing tergambar dalam 
beberapa penelitian terdahulu oleh Zhou et al. (2009), Jung \& Sung (2008) dan Liaogang et al. (2007) yang menjelaskan adanya perbedaan penilaian ekuitas merek diantara merek lokal dan merek asing.

Propinsi Kalimantan Barat merupakan salah satu propinsi di Indonesia yang memiliki kedekatan geografis dengan negara Malaysia dimana terdapat lima kabupaten yang berbatasan langsung dengan wilayah Malaysia yaitu Kabupaten Sambas, Kabupaten Bengkayang, Kabupaten Sanggau, Kabupaten Sintang Dan Kabupaten Kapuas Hulu. Keadaan ini semakin mempermudah arus masuknya produk makanan olahan dari negara tersebut ke wilayah Kalimantan Barat, terutama di kota Pontianak sebagai ibukota propinsi. Produk makanan olahan dari Malaysia banyak tersebar di pasar Pontianak sehingga tidak sulit bagi konsumen untuk mendapatkannya. Jenis makanan olahan Malaysia bervariasi diantaranya pada jenis produk wafer, snack, cracker, coklat dan biskuit.

Merek produk makanan olahan Malaysia menyaingi produk makanan olahan domestik. Berdasarkan informasi yang diperoleh dari pedagang pada sembilan toko swalayan besar di kota Pontianak menjelaskan bahwa persaingan sangat dekat terjadi pada kategori biskuit yaitu antara biskuit merek domestik yaitu merek Roma, Khong Guan, Dane's dan Unibis dengan biskuit merek Malaysia yaitu merek Pimpong, Munchys, Hup Seng dan Shoon Fat. Merek-merek biskuit tersebut bersaing dekat pada kelas produk yang sama dari faktor harga, rasa, dan kemasan. Karena alasan inilah maka untuk kategori produk keterlibatan rendah, penelitian ini akan dilakukan dengan menfokuskan pada merek biskuit yang berasal dari Malaysia dan Indonesia.

Keberadaan merek asing yang semakin menjamur tentunya memberikan ancaman bagi kondisi domestik. Upaya untuk meningkatkan loyalitas pelanggan pada merek domestik perlu ditingkatkan. Untuk itu, pemahaman perilaku konsumen yang berkaitan dengan penilaian mereka pada merek domestik maupun merek asing perlu dilakukan. Alasan konsumen lebih tertarik pada merek asing perlu dikaji lebih lanjut, termasuk faktor yang mendorong mereka loyal terhadap merek asing tersebut. Atas alasan inilah maka penelitian ini ingin mempelajari repon pelanggan atas merek biskuit Malaysia dan Indonesia dalam hal kesadaran merek, asosiasi merek, kualitas yang dirasakan atas merek, serta perilaku loyalitas pelanggan pada merek tersebut.

\section{LANDASAN TEORI}

\subsection{Pengertian Dan Arti Penting Ekuitas Merek}

Dalam pengertian umum, ekuitas merek didefinisikan sebagai efek pemasaran yang unik yang muncul pada merek. Artinya, ekuitas merek berkaitan dengan kenyataan bahwa perbedaan hasil dari kegiatan pemasaran suatu produk atau jasa dikarenakan elemen merek, dibandingkan dengan hasil yang diperoleh jika produk atau jasa yang sama 
tidak memiliki identifikasi merek. Meskipun terdapat sejumlah pandangan yang berbeda dari ekuitas merek, namun secara umum dan konsisten suatu gagasan dasar ekuitas merek merupakan "nilai tambah" yang diberikan pada sebuah produk atau layanan sebagai akibat investasi masa lalu dalam pemasaran merek.

Menurut Aaker (1991), ekuitas merek terdiri dari lima dimensi aset yang berbeda. Aset ini meliputi : 1) loyalitas merek, 2) kesadaran merek, 3) persepsi kualitas, 4) asosiasi merek, dan 5) aset kepemilikan lainnya seperti paten, merek dagang dan hubungan saluran. Keller (1993) dan Keller (1998). Menyatakan bahwa ekuitas merek secara implisit menjelaskan tentang berbagai cara bagaimana nilai dapat diciptakan untuk sebuah merek, ekuitas merek menyediakan suatu common denominator untuk menginterpretasikan strategi pemasaran dan mengukur nilai dari sebuah merek, dan terdapat banyak cara berbeda dimana nilai sebuah merek dapat diwujudkan atau dimanfaatkan untuk keuntungan perusahaan.

Terdapat dua alasan umum untuk mempelajari ekuitas merek, dimana menurut Keller (1993) alasan pertama adalah motivasi berbasis finansial untuk memperkirakan nilai dari sebuah merek yang lebih tepat untuk tujuan akuntansi dalam hal penilaian aset untuk neraca atau untuk tujuan merger, akuisisi atau divestasi. Alasan kedua mempelajari ekuitas merek muncul dari strategi yang berbasis motivasi untuk meningkatkan produktivitas pemasaran. Mengingat biaya yanglebih tinggi, kompetisi yang lebih besar, dan permintaan di banyak pasar, perusahaan berusaha untuk meningkatkan efisiensi biaya pemasaran mereka. Sebagai akibatnya, pemasar membutuhkan pemahaman yang lebih menyeluruh dari perilaku konsumen sebagai dasar untuk membuat keputusan strategis yang lebih baik tentang definisi pasar sasaran dan positioning produk. Salah satu aset perusahaan yang paling berharga untuk meningkatkan produktivitas pemasaran adalah pengetahuan merek dibenak konsumen yang dihasilkan dari investasi perusahaan dalam program pemasaran sebelumnya. Masalah penilaian keuangan memiliki sedikit relevansi jika tidak ada yang mendasari nilai merek yang telah dibuat atau jika manajer tidak mengetahui bagaimana memanfaatkan nilai dari pengembangan strategi merek yang menguntungkan.

\subsection{Kualitas Yang Dirasakan (Perceived Quality)}

Kualitas yang dirasakan didefinisikan sebagai persepsi pelanggan terhadap keseluruhan kualitas relatif atau superioritas suatu produk atau jasa terhadap pilihanpilihan yang ada. Kesan kualitas tidak bisa ditentukan secara obyektif, karena kesan kualitas itu sendiri adalah sebuah ringkasan konstruk (Aaker, 1991). Kualitas yang dirasakan sangat penting dalam beberapa hal. Dalam banyak konteks, kulitas yang dirasakan atau kesan kualitas dari merek memberikan alasan penting untuk membeli. Hal ini mempengaruhi merek mana yang dimasukkan dan tidak dimasukkan dalam pertimbangan merek yang akan dipilih. Keuntungan kesan kualitas memberikan pilihan untuk menetapkan suatu harga premium. 
Harga premium dapat meningkatkan keuntungan dan / atau menyediakan sumber daya yang dapat digunakan untuk berinvestasi kembali dalam hal merek. Kesan kualitas juga dapat berarti bagi pengecer, distributor dan anggota saluran lainnya dan dengan demikian membantu dalam pendistribusian. Anggota saluran termotivasi untuk mempromosikan merek. Selain itu, kesan kualitas dapat dimanfaatkan untuk memperkenalkan perluasan merek, menggunakan nama merek pada kategori produk baru. Sebuah merek yang kuat dengan kesan kualitas yang baik akan dapat diperluas lebih lanjut, dan akan memberikan kemungkinan keberhasilan yang lebih tinggi dari pada merek yang lemah (Aaker, 1991).

Berbagai dimensi yang mendasari penilaian kesan kualitas akan bergantung pada konteksnya. Untuk mempelajari dimensi-dimensi yang relevan dalam konteks tertentu, biasanya berguna untuk mengadakan beberapa riset. Aaker (1991) merangkum dimensidimensi kualitas produk dan kualitas pelayanan yang dikemukakan oleh David A.Garvin dan Parasuraman, Zeithaml and Berry. Dimensi kualitas produk menurut David A.Garvin (1984) dalam Aaker (1991) meliputi :

1. Kinerja , seberapa efektif sebuah mesin cuci dalam membersihkan pakaian

2. Karakteristik produk, apakah suatu pasta gigi memiliki tube yang praktis.

3. Kesesuaian dengan spesifikasi, dalam hal apa terjadi penyimpangan spesifikasi.

4. Keandalan, bisakah suatu mesin pemotong rumput ini bekerja dengan semestinya setiap kali dipakai.

5. Ketahanan, berapa lama mesin pemotong rumput inibisa bertahan

6. Pelayanan, apakah sistem pelayanannya efisien, kompeten, dan nyaman.

7. Hasil akhir, apakah produk tersebut tampak dan terkesan seperti produk yang berkualitas.

Sedangkan dimensi kualitas pelayanan menurut Parasuraman, Zeithaml and Berry (1985) dalam Aaker (1991) meliputi :

1. Bentuk fisik, apakah fasilitas fisik, perlengkapan, dan penampilan dari para pekerjanya mengesankan kualitas.

2. Keandalan, bisakah tugas akuntansi itu diketjakan dengan meyakinkan dan akurat.

3. Kompetensi, apakah staf revisi operasi itu mempunyai pengeyahuan dan keahlian dalam mengerjakan tugas itu dengan semestinya. Apakah mereka mengesankan keyakinan dan rasa percaya diri.

4. Tanggung jawab, apakah staf wiraniaganya berkemauan untuk membantu para pelanggan dan memberikan layanan dengan sebaik-baiknya.

5. Empati, apakah sebuah bank menunjukkan rasa peduli dan perhatian pada setiap kepribadian dari para pelanggannya.

Kesan kualitas berbeda dengan kepuasan. Seorang pelanggan bisa dipuaskan karena ia mempunyai harapan yang rendah terhadap konerjanya. Namun, kesan kualitas yang tinggi tidak identik dengan harapan pelanggan yang rendah. Meskipun kesan 
kualitas berbeda dengan sikap, suatu sikap positif bisa ditimbulkan karena suatu produk dengan kualitas rendah sangat murah. Sebaliknya, seseorang mungkin mempunyai sikap negatif terhadap produk berkualitas tinggi yang harganya terlalu mahal. Dalam banyak hal, kesan kualitas atas sebuah merek akan memberikan alasan yang kuat bagi pembeli untuk mempengaruhi merek-merek mana yang perlu dipertimbangkan dan pada gilirannya mempengaruhi merek apa yang bakal dipilih.

\subsection{Asosiasi Merek}

Asosiasi Merek adalah segala sesuatu yang terkait dalam memori konsumen tentang sebuah merek (Aaker, 1991). Asosiasi merek dapat dilihat dalam segala bentuk dan mencerminkan fitur produk atau aspek independen dari produk itu sendiri (Chen, 2001). Asosiasi ini bukan hanya ada tetapi juga memiliki tingkat kekuatan. Posisi merek didasarkan pada asosiasi dan bagaimana mereka berbeda dari pesaing. Sebuah asosiasi dapat mempengaruhi proses dan pengingatan kembali informasi, memberikan titik diferensiasi, memberikan alasan untuk membeli, menciptakan sikap positif dan perasaan dan melayani sebagai dasar perluasan. Asosiasi nama merek yang mapan dapat mempengaruhi perilaku pembelian dan mempengaruhi kepuasan pengguna. Bahkan ketika asosiasi tersebut tidak penting bagi pilihan merek, mereka dapat meyakinkan, mengurangi insentif untuk mencoba merek lain.

Posisi merek didasarkan pada asosiasi dan bagaimana mereka berbeda dari pesaing. Sebuah asosiasi dapat mempengaruhi proses dan pengingatan kembali informasi, memberikan titik diferensiasi, memberikan alasan untuk membeli, menciptakan sikap positif dan perasaan dan melayani sebagai dasar perluasan. Asosiasi nama merek yang mapan dapat mempengaruhi perilaku pembelian dan mempengaruhi kepuasan pengguna. Bahkan ketika asosiasi tersebut tidak penting bagi pilihan merek, mereka dapat meyakinkan, mengurangi insentif untuk mencoba merek lain (Aaker,1991). Ekuitas merek berbasis pelanggan terjadi ketika pelanggan memiliki tingkat kesadaran yang tinggi dan memegang asosiasi merek yang menguntungkan dan unik dalam ingatan mereka.

Nilai yang mendasari sebuah merek seringkali merupakan sekumpulan asosiasinya, dengan kata lain merupakan makna merek tersebut bagi khalayak. Asosiasi-asosiasi menjadi pijakan dalam keputusan-keputusan pembelian dan loyalitas merek. Ada banyak sekali kemungkinan asosiasi, dan suatu variasi dari asosiasi-asosiasi bisa memberikan nilai. Aaker (1991) mengemukakan sebelas tipe asosiasi, yaitu: atribut produk, barang tak berwujud, manfaat bagi pelanggan, harga relatif, penggunaan atau aplikasi, pengguna atau pelanggan, orang terkenal, gaya hidup atau kepribadian, kelas produk, para kompetitor dan negara atau wilayah geografis. Ekuitas merek sebagian besar didukung oleh asosiasi pelanggan dengan merek, yang memberikan kontribusi pada citra merek tertentu. 
Komponen asosiasi biasanya meliputi dimensi citra yang memberikan keunikan pada suatu kelas produk atau pada suatu merek. Pengukuran asosiasi merek tersusun dalam tiga perspectif (Aaker, 1996) yaitu: merek sebagai produk/nilai (the brand as product/value), merek sebagai orang (the brand as person), dan merek sebagai organisasi (the brand as organization). Asosiasi merek menurut Keller (1993) dibedakan berdasarkan tingkat abstraksi, maksudnya berdasarkan pada seberapa banyak informasi dimasukkan dalam asosiasi. Dalam hal ini, jenis asosiasi merek dapat dikelompokkan menjadi tiga yaitu : 1) atribut, 2) manfaat, dan 3) sikap.

Berbagai jenis asosiasi merek dapat bervariasi sesuai dengan favourability/ kesukaan mereka, kekuatan, dan keunikan. Asosiasi merek berbeda sesuai dengan bagaimana mereka dievaluasi. Keberhasilan program pemasaran tercermin dalam penciptaan asosiasi merek yang menguntungkan, yaitu konsumen percaya bahwa merek memiliki atribut dan manfaat yang memuaskan kebutuhan dan keinginan mereka, sehingga keseluruhan sikap merek yang positif terbentuk. Kekuatan asosiasi merek tergantung pada bagaimana informasi masuk memori konsumen dan bagaimana hal itu dipertahankan sebagai bagian citra merek. Adanya asosiasi yang dievaluasi secara kuat dan menyenangkan akan menjadikan keunikan bagi merek dan menyiratkan keunggulan yang lebih dari merek lain, hal ini penting bagi suatu merek sukses. Namun, dikala merek tidak memiliki pesaing, suatu merek kemungkinan besar akan berbagi beberapa asosiasi dengan merek lain.

Kesukaan dan kekuatan asosiasi merek dapat dipengaruhi oleh asosiasi merek lainnya dalam memori. Kesesuaian ini didefinisikan sebagai sejauh mana suatu asosiasi merek terbagi dan bermakna dengan asosiasi merek lainnya. Keller (1993) dan Keller (1998) menyatakan bahwa secara umum, informasi yang konsisten yang terangkum dalam asosiasi merek akan lebih mudah diingat dan dipahami konsumen dari pada informasi yang tidak berhubungan, dimana kesesuaian diantara asosiasi-asosiasi merek ini akan menentukan kohesifitas citra merek.

Asosiasi merek sekunder terjadi ketika asosiasi merek itu sendiri terkait dengan informasi yang diingat lainnya yang secara tidak langsung berhubungan dengan produk atau layanan. Karena merek menjadi diidentifikasi dengan entitas lain, konsumen dapat menarik kesimpulan bahwa merek membagi asosiasi dengan entitas, sehingga menghasilkan hubungan tidak langsung dengan merek. Keller (1993) dan Keller (1998) mengemukakan bahwa asosiasi sekunder mungkin timbul dari asosiasi yang berhubungan, misalnya berhubungan dengan perusahaan, negara asal, distribusi saluran, seorang selebriti dari produk atau layanan, atau peristiwa. Tiga jenis asosiasi sekunder pertama melibatkan sumber faktual bagi merek. Pertama, merek mungkin berbeda sejauh yang diidentifikasi dengan sebuah perusahaan tertentu. Demikian pula, sebuah merek dapat berhubungan dengan "negara asal" nya sedemikian rupa sehingga konsumen menyimpulkan keyakinan spesifik dan evaluasi. Akhirnya, jalur distribusi produk juga dapat membuat asosiasi sekunder. Jenis asosiasi sekunder yang kedua terakhir terjadi 
ketika asosiasi merek utama terkait dengan situasi atribut pengguna dan penggunaan, terutama ketika melibatkan orang atau peristiwa tertentu. Kasus di mana seseorang terkenal meminjamkan kredibilitas untuk produk atau pelayanan karena keahlian nya, kepercayaan, atau daya tarik. Hal serupa terjadi ketika merek menjadi terkait dengan suatu peristiwa, beberapa asosiasi terkait dengan peristiwa dapat secara tidak langsung berhubungan dengan merek. Asosiasi merek sekunder menjadi penting jika keberadaan asosiasi merek kurang memadai dalam beberapa cara. Dengan kata lain, asosiasi sekunder dimanfaatkan untuk membuat asosiasi yang menguntungkan, kuat, dan unik .

\subsection{Loyalitas Merek}

Loyalitas merek merupakan sikap yang menguntungkan terhadap merek yang dicerminkan oleh pembelian merek yang konsisten dari waktu ke waktu. Loyalitas merek merupakan hasil pembelajaran konsumen dimana hanya merek tertentu dapat memenuhi kebutuhan mereka. Peter \& Olson (1999) menyatakan bahwa terdapat dua pendekatan dalam mempelajari loyalitas. Pendekatan pertama adalah pendekatan perilaku yang memandang loyalitas merek diindikasikan sebagai pembelian yang konsisten terhadap suatu merek dari waktu ke waktu.

Ukuran perilaku mendefinisikan loyalitas dari frekuensi pembelian dan/atau proporsi pembelian. Perilaku pembelian ulang diasumsikan untuk mencerminkan penguatan dan keterkaitan yang kuat antara rangsangan dan respon. Namun, beberapa loyalitas mungkin saja kurang memiliki komitmen terhadap merek dan mencerminkan pembelian ulang yang membeli berdasarkan kebiasaan. Pendekatan kedua adalah pendekatan kognitif, dimana komitmen terhadap sebuah merek yang tidak tercermin sebagai ukuran perilaku yang terus menerus. Sebuah keluarga dapat membeli merek tertentu dikarenakan harga merek di pasar paling rendah. Sedikit peningkatan harga dapat menyebabkan keluarga tersebut bergeser ke merek yang lain. Dalam hal ini, pembelian terus menerus tidak mencerminkan penguatan atau kesetiaan.

Loyalitas merek, yang dapat mencerminkan gambaran dari kebiasaan pembeli yang puas seperti merek yang benar-benar memiliki komitmen, menghasilkan nilai terutama dengan mengurangi biaya pemasaran, mempertahankan pelanggan yangsudah ada jauh lebih murah dari pada menarik yang baru (Aaker, 1992). Tentunya akan sulit bagi pesaing untuk berkomunikasi dengan pengguna merek yang puas, karena mereka memiliki sedikit motivasi untuk mempelajari berbagai pilihan. Dalam kondisi demikian, merek pesaing dihadapkan pada tantangan yang besar. Pada kenyataannya, seringkali kesalahan yang umum terjadi adalah berupaya meningkatkan penjualan dengan menarik pelanggan merek yang baru, sementara mengabaikan pelanggan yang ada saat ini, padahal pada kenyatannya pelanggan setia dapat menarik orang lain dengan menggunakan produk atau mendorong orang lain untuk menggunakannya. 
Loyalitas merek berbasis pelanggan sering menjadi inti dari ekuitas merek. Hal ini mencerminkan bagaimana seorang pelanggan akan tidak berkeinginan untuk beralih ke merek lain, apalagi ketika pada merek terjadi perubahan, baik dalam harga maupun fitur produk. Menurut Aaker (1991) ada lima tingkat potensial loyalitas. Tingkat-tingkat ini tidaklah selalu muncul dalam bentuk murni. Kelima tingkatan ini memberikan perasaan pada berbagai bentuk kesetiaan yang dapat terjadi, yang berdampak pada ekuitas merek.

1) Tingkat loyalitas paling dasar adalah pembeli yang tidak loyal/setia yang benar-benar tidak peduli dengan merek. Setiap merek dianggap memadai, dan nama merek hanya memainkan peran kecil dalam keputusan pembelian. Pembeli ini disebut seorang switcher.

2) Tingkat kedua mencakup pembeli yang puas dengan produk, dimana terjadinya pembelian produk lebih dikarenakan faktor kebiasaan. Para pembeli ini disebut habitual buyer.

3) Tingkat ketiga terdiri dari mereka yang juga puas dan, di samping itu, mempertimbangkan biaya beralih, misalnya biaya waktu atau uang yang terkait dengan tindakan beralih. Kelompok ini disebut loyalitas biaya beralih.

4) Tingkat keempat adalah orang-orang yang benar-benar menyukai merek. Preferensi mereka didasarkan pada simbol, seperangkat pengalaman menggunakan atau merasakan kualitas tinggi. Segmen pada tingkat keempat ini disebut sahabat merek, karena terdapat sentuhan perasaan /emosi.

5) Pada tingkat teratas adalah pelanggan yang berkomitmen. Mereka merasa bangga menjadi pengguna merek. Merek sangat penting bagi mereka baik fungsional maupun sebagai ungkapan siapa mereka. Kepercayaan mereka pada merek membuat mereka akan merekomendasikan hal ini kepada orang lain.

Loyalitas merek dari pelanggan yang ada saat ini merupakan aset strategis yang jika dikelola dengan benar dan dieksploitasi, memiliki potensi untuk memberikan nilai dalam beberapa cara. Aaker (1991) mengemukakan bahwa pelanggan yang setia dapat mengurangi biaya pemasaran, karena jauh lebih murah untuk mempertahankan pelanggan dari pada memperoleh dan mendapatkan kembali pelanggan baru, dan memberikan pengaruh perdagangan terhadap orang lain dalam saluran distribusi. Pelanggan dapat menciptakan brand awareness dan menghasilkan kepastian untuk pelanggan baru. Pelanggan yang setia juga akan memberikan waktu bagi perusahaan untuk merespon ancaman kompetitif.

\section{METODE PENELITIAN}

\subsection{Rancangan Penelitian}

Penelitian ini merupakan penelitian dalam bidang ilmu manajemen pemasaran terutama yang memfokuskan pada bidang manajemen pemasaran internasional dan perilaku konsumen secara lebih khusus dalam kajian tentang ekuitas merek berbasis 
konsumen. Pengamatan dilakukan pada pelanggan produk makanan olahan biskuit di kota Pontianak.

Rancangan dalam penelitian ini merupakan rancangan penelitian konklusif. Penelitian konklusif bersifat lebih formal dan terstruktur daripada penelitian eksploratif. Maholtra, (2004) mengemukakan bahwa penelitian konsklusif didasarkan pada sampel besar yang representatif dan data yang dihasilkan dianalisis secara kuantitatif. Penelitian ini bermaksud untuk mengetahui tanggapan responden tentang ekuitas merek produk makanan olahan khususnya merek biskuit buatan Indonesia dan Malaysia.

\subsection{Populasi dan Sampel}

Populasi adalah keseluruhan kelompok orang, kejadian, atau hal minat yang ingin peneliti investigasi (Sekaran, 2003). Agar penelitian ini mampu menjawab seluruh permasalahan yang diajukan dalam penelitian dan mampu mencapai tujuan penelitian yang diinginkan, maka perlu ditentukan populasi sasaran. Populasi sasaran dalam penelitian ini adalah konsumen biskuit merek buatan Malaysia Dan Indonesia. Merek biskuit Malaysia yang diteliti adalah merek Pimpong, Munchys, Hup Seng, Shoon Fat. Merek biskuit buatan Indonesia yang diteliti adalah, Roma, Khong Guan, Dane's dan Unibis.

Dalam penelitian ini, peneliti menggunakan teknik penarikan sample nonprobability samplingbe rupa purposive sampling, yaitu teknik pengambilan sampel dengan mempertimbangkan kriteria yaitu responden berperan sebagai decider dan user merek biskuit buatan Malaysia dan atau Indonesia. Jumlah sampel dalam penelitian ini berjumlah 160 responden, terdiri atas 80 responden konsumen merek biskuit buatan Malaysia dan 80 responden konsumen merek biskuit buatan Indonesia. Alokasi sampel dikemukakan sebagai berikut :

Tabel 1. Alokasi Sampel

\begin{tabular}{|c|c|}
\hline Merek & Jumlah Sampel \\
\hline Merek biskuit buatan Indonesia : & 80 \\
\hline 1. Roma & 20 \\
\hline 2. Khong Guan & 20 \\
\hline 3. Dane's & 20 \\
\hline 4. Unibis & 20 \\
\hline Merek biskuit buatan Malaysia : & 80 \\
\hline 1. Munchy's & 20 \\
\hline 2. Hupseng & 20 \\
\hline 3. Pimpong & 20 \\
\hline 4. Shoon Fat & 20 \\
\hline Jumlah Responden & 160 \\
\hline
\end{tabular}




\subsection{Variabel Penelitian}

Agar diperoleh data yang lengkap dan akurat maka perlu dibuat definisi operasional variabel sebagai dasar untuk membuat pertanyaan yang diperkirakan valid dan reliabel.

\section{1) Asosiasi Merek (Brand Association)}

Asosiasi merek adalah persepsi pelanggan terhadap segala hal yang berkaitan dengan ingatan pelanggan mengenai suatu merek biskuit buatan Malaysia/Indonesia (Aaker, 1996; Keller, 1993, 2008). Indikator yang digunakan adalah sebagai berikut: Sudah lama ada di pasar, dikenal sebagai merek terpercaya, harga sesuai dengan manfaat, unggul dalam kategori produk, lebih banyak diminati, praktis dikonsumsi, dan variasi rasa yang nikmat.

\section{2) Kualitas Yang Dirasakan (Perceived Quality)}

Kualitas yang dirasakan adalah persepsi pelanggan terhadap keseluruhan kualitas dan keunggulan produk dari merek biskuit buatan Malaysia / Indonesia yang dikonsumsi (David A.Garvin, 1984; Aaker ,1991). Indikator yang digunakan adalah sebagai berikut : rasa biskuit, kandungan bahan, disain kemasan, kemasan, informasi tentang komposisi bahan, dan informasi tentang waktu kadaluarsa.

\section{3) Loyalitas Merek (Brand Loyalty)}

Loyalitas merek adalah kecendrungan pelanggan untuk setia dan bersikap positif terhadap merek biskuit, memiliki komitmen dan niat pembelian ulang di masa mendatang pada merek biskuit tersebut (Aaker, 1991; Mowen \& Minor, 2001). Indikator yang digunakan adalah sebagai berikut : pilihan pertama, menceritakan halhal positif, merekomendasikan pada orang lain, dan harga premium.

\subsection{Pengumpulan Data}

Data yang dikumpulkan dalam penelitian ini meliputi data primer dan data sekunder. Data primer yaitu data yang penulis kumpulkan sendiri dan olah sendiri berdasarkan informasi-informasi/masukan-masukan yang diperoleh dari lapangan melalui:

1. Wawancara, yaitu mengadakan tanya jawab secara langsung dengan responden

2. Kuesioner, yaitu suatu cara pengumpulan data dengan menyebarkan daftar pertanyaan yang berhubungan dengan masalah yang diteliti kepada responden.

3. Survei Lapangan, yaitu pengamatan secara langsung terhadap kenyataan pragmatis pemasaran produk biskuit khususnya pada merek biskuit buatan Malaysia dan Indonesia di Pontianak yang melibatkan sikap dan perilaku responden.

Data sekunder yaitu data yang diperoleh dalam bentuk yang sudah jadi. Dalam hal ini, data diperoleh dari:

a. Studi dokumentasi, yaitu melalui penelusuran publikasi pemasaran produk biskuit dengan merek dari Malaysia dan Indonesia pada media cetak dan elektronik . 
b. Studi kepustakaan; yaitu dengan melakukan penelaahan literatur yang berhubungan dengan permasalahan yang diteliti penulis.

\subsection{Teknik Analisa Data}

Untuk menganalisis perbedaan antara ekuitas merek biskuit buatan Indonesia dan buatan Malaysia, dan menguji hipotesis yang telah dirumuskan dalam penelitian ini digunakan analisis kuantitatif berupa One Way Anova.

Tabel 2. Karakteristik Responden

\begin{tabular}{|c|c|c|c|c|c|}
\hline \multicolumn{2}{|r|}{ Profil Responden } & \multicolumn{2}{|c|}{$\begin{array}{c}\text { Merek Biskuit } \\
\text { Indonesia }\end{array}$} & \multicolumn{2}{|c|}{$\begin{array}{c}\text { Merek Biskuit } \\
\text { Malaysia }\end{array}$} \\
\hline & & $\begin{array}{c}\text { Jumlah } \\
\text { Resp. }\end{array}$ & Frekuensi & $\begin{array}{c}\text { Jumlah } \\
\text { Resp. }\end{array}$ & Frekuensi \\
\hline Jenis & Laki-Laki & 47 & $29,38 \%$ & 35 & $43,75 \%$ \\
\hline Kelamin & Perempuan & 33 & $20,63 \%$ & 38 & $47,50 \%$ \\
\hline Usia & $\begin{array}{l}<20 \text { tahun } \\
>20 \text { tahun }\end{array}$ & $\begin{array}{l}49 \\
22\end{array}$ & $\begin{array}{l}30,63 \% \\
13,80 \%\end{array}$ & $\begin{array}{l}64 \\
16\end{array}$ & $\begin{array}{l}80 \% \\
20 \%\end{array}$ \\
\hline Pendapatan & $\begin{array}{c}<\operatorname{Rp~1.000.000,-} \\
>\operatorname{Rp} 1.000 .000,- \text { sd Rp } 2.000 .000,- \\
>\operatorname{Rp} 2.000 .000,- \text { sd Rp } 3.000 .000,- \\
>\operatorname{Rp} 3.000 .000,- \text { sd Rp } 4.000 .000,- \\
>\operatorname{Rp} 4.000 .000,- \text { sd Rp } 5.000 .000,- \\
>\operatorname{Rp} 5.000 .000,- \text { sd Rp 6.000.000,- } \\
>\text { Rp 6.000.000,- } \\
\text { Missing }\end{array}$ & $\begin{array}{l}18 \\
27 \\
12 \\
10 \\
3 \\
1 \\
4 \\
5\end{array}$ & $\begin{array}{c}22,5 \% \\
33,75 \% \\
15 \% \\
12,5 \% \\
3,75 \% \\
1,25 \% \\
5 \% \\
6,25 \%\end{array}$ & $\begin{array}{l}14 \\
27 \\
19 \\
12 \\
3 \\
3 \\
2 \\
0\end{array}$ & $\begin{array}{c}17,50 \% \\
33,75 \% \\
23,75 \% \\
15,00 \% \\
3,75 \% \\
3,75 \% \\
2,5 \% \\
0 \%\end{array}$ \\
\hline $\begin{array}{c}\text { Sumber } \\
\text { Informasi } \\
\text { Tentang } \\
\text { merek } \\
\text { Biskuit }\end{array}$ & $\begin{array}{l}\text { Tenaga Penjual } \\
\text { Teman } \\
\text { Keluarga } \\
\text { Toko } \\
\text { Biskuit itu sendiri } \\
\text { Sumber Informasi lainnya } \\
\text { Missing }\end{array}$ & $\begin{array}{c}6 \\
17 \\
12 \\
27 \\
40 \\
29 \\
1\end{array}$ & $\begin{array}{c}7,50 \% \\
21,25 \% \\
15,00 \% \\
33,75 \% \\
50,00 \% \\
36,25 \% \\
1,25 \% \\
\end{array}$ & $\begin{array}{c}5 \\
23 \\
13 \\
38 \\
28 \\
2 \\
0\end{array}$ & $\begin{array}{c}6,25 \% \\
28,75 \% \\
16,25 \% \\
47,50 \% \\
35 \% \\
2,5 \% \\
0 \%\end{array}$ \\
\hline
\end{tabular}

\section{PEMBAHASAN}

\subsection{Karakteristik Responden}

Karakteristik responden dalam penelitian ini dikemukakan secara terperinci pada Tabel 2. Tabel 2 menginformasikan bahwa sebagian besar responden merek biskuit buatan Indonesia berjenis kelamin laki-laki, berpenghasilan antara Rp 2 juta hingga Rp 3 juta dan memperoleh informasi tentang merek biskuit dari keberadaan biskuit itu sendiri dan iklan televisi. Untuk merek biskuit buatan Malaysia, sebagian besar responden berjenis kelamin perempuan, berusia kurang dari 20 tahun, berpenghasilan antara Rp 1 juta hingga Rp 2 juta, dan memperoleh informasi tentang merek biskuit Malaysia tersebut dari toko. 
Berikut ini dikemukakan berbagai alasan responden mengkonsumsi biskut yang berasal dari Malaysia dan Indonesia.

Tabel 3. Alasan Responden Membeli Merek Biskuit

\begin{tabular}{lcccc}
\hline \multicolumn{1}{c}{ Alasan Responden } & \multicolumn{2}{c}{$\begin{array}{c}\text { Merek Biskuit } \\
\text { Indonesia }\end{array}$} & \multicolumn{2}{c}{$\begin{array}{c}\text { Merek Biskuit } \\
\text { Malaysia }\end{array}$} \\
\cline { 2 - 5 } & $\begin{array}{c}\text { Jumlah } \\
\text { Responden }\end{array}$ & Frekuensi & $\begin{array}{c}\text { Jumlah } \\
\text { Responden }\end{array}$ & Frekuensi \\
\hline Rasanya enak dan gurih & 36 & $45 \%$ & 28 & $35,00 \%$ \\
Banyak pilihan rasa & 10 & $12,5 \%$ & 0 & $0 \%$ \\
Harga terjangkau & 9 & $11,25 \%$ & 13 & $16,25 \%$ \\
Kualitas terjamin & 4 & $5 \%$ & 0 & $0 \%$ \\
Mudah didapat & 3 & $3,75 \%$ & 2 & $2,5 \%$ \\
Merupakan produk dalam negeri & 3 & $3,75 \%$ & $0 \%$ & $0 \%$ \\
Kemasan Menarik & 1 & $1,25 \%$ & 5 & $6,25 \%$ \\
Rasanya sesuai dengan cita rasa & 2 & $2,5 \%$ & 0 & $0 \%$ \\
orang Indonesia & & & \multicolumn{2}{c}{} \\
Dikenal banyak orang & 6 & $7,5 \%$ & 0 & $0 \%$ \\
Banyak pilihan rasa & 4 & $5 \%$ & 1 & $1,25 \%$ \\
Aman dikonsumsi & 0 & $0 \%$ & 2 & $2,50 \%$ \\
Mengandung nilai gisi & 0 & $0 \%$ & 3 & $3,75 \%$ \\
\multicolumn{1}{c}{ Jumlah } & 80 & & 80 & \\
\hline
\end{tabular}

Tabel 3 menjelaskan bahwa sebagian besar responden yang mengkonsumsi biskuit buatan Indonesia, mengkonsumsi biskuit tersebut lebih banyak dikarenakan rasanya yang enak dan gurih, banyak pilihan rasa dan harganya yang terjangkau. Cenderung serupa dengan responden biskuit buatan Indonesia, alasan sebagian besar responden yang mengkonsumsi biskuit buatan Malaysia juga dikarenakan rasa yang enak, harga terjangkau dan kemasan menarik.

\subsection{Uji Validitas Dan Reliabilitas}

Uji validitas item digunakan untuk mengukur ketepatan suatu item dalam kuesioner, apakah item-item tersebut sudah tepat dalam mengukur apa yang ingin diukur. Pengujian dilakukan dengan metode korelasi Pearson yaitu dengan mengkorelasikan skor item dengan skor total. Kriteria uji validitas dilihat dari nilai korelasi pearson yang dihasilkan harus lebih besar dari nilai $r$ tabel. Nilai $r$ tabel sebesar 0,361 (jumlah sampel 30 dan taraf signifikansi 0,05). Hasil uji validitas dikemukakan pada Tabel 4. Berdasarkan Tabel 4, diketahui bahwa keseluruhan item adalah valid, dimana nilai $\mathrm{r}$ hitung lebih besar dari pada nilai $r$ tabel.

Uji reliabilitas digunakan untuk mengetahui konsistensi alat ukur, apakah alat pengukur yang digunakan dapat diandalhan dan tetap konsisten jika pengukuran tersebut diulang. Metode uji reliabilitas yang sering digunakan adalah Cronbach's Alpha. Untuk menentukan apakah instrumen reliabel atau tidak, dapat menggunakan suatu batasan tertentu. Menurut Sekaran (1992), reliabilitas kurang dari 0,6 adalah kurang baik, 
sedangkan 0,7 dapat diterima dan di atas 0,8 adalah baik. Hasil pengujuan reliabilitas dalam penelitian ini dikemukakan pada Tabel 5. Informasi dari Tabel 5 menunjukkan bahwa nilai alpha cronbach untuk semua item lebih besar dari 0,6. Artinya bahwa semua item dinyatakan reliabel.

Tabel 4. Uji Validitas

\begin{tabular}{cccc}
\hline ITEM & $\begin{array}{c}\text { NILAI KORELASI } \\
\text { PEARSON }\end{array}$ & NILAI r tabel & INTERPRETASI \\
\hline Item 1_Brand Ass & 0,802 & 0,361 & Valid \\
Item 2_Brand Ass & 0,841 & 0,361 & Valid \\
Item 3_Brand Ass & 0,513 & 0,361 & Valid \\
Item 4_Brand Ass & 0,875 & 0,361 & Valid \\
Item 5_Brand Ass & 0,640 & 0,361 & Valid \\
Item 6_Brand Ass & 0,635 & 0,361 & Valid \\
Item 7_Brand Ass & 0,638 & 0,361 & Valid \\
Item 1_Perceived Qual & 0,710 & 0,361 & Valid \\
Item 2_Perceived Qual & 0,735 & 0,361 & Valid \\
Item 3_Perceived Qual & 0,786 & 0,361 & Valid \\
Item 4_Perceived Qual & 0,675 & 0,361 & Valid \\
Item 5_Perceived Qual & 0,895 & 0,361 & Valid \\
Item 6_Perceived Qual & 0,474 & 0,361 & Valid \\
& & & \\
Item 1_Brand Loy & 0,847 & 0,361 & Valid \\
Item 2_Brand Loy & 0,817 & 0,361 & Valid \\
Item 3_Brand Loy & 0,885 & 0,361 & Valid \\
Item 4_Brand Loy & 0,969 & 0,361 & Valid \\
\hline
\end{tabular}

Tabel 5. Uji Reliabilitas

\begin{tabular}{cc}
\hline Item & Cronbach's Alpha \\
\hline Item 1_Brand Ass & 0,729 \\
Item 2_Brand Ass & 0,741 \\
Item 3_Brand Ass & 0,766 \\
Item 4_Brand Ass & 0,719 \\
Item 5_Brand Ass & 0,759 \\
Item 6_Brand Ass & 0,759 \\
Item 7_Brand Ass & 0,756 \\
& \\
Item 1_Perceived Qual & 0,775 \\
Item 2_Perceived Qual & 0,764 \\
Item 3_Perceived Qual & 0,760 \\
Item 4_Perceived Qual & 0,782 \\
Item 5_Perceived Qual & 0,717 \\
Item 6_Perceived Qual & 0,825 \\
Item 1_Brand Loy & 0,894 \\
Item 2_Brand Loy & 0,908 \\
Item 3_Brand Loy & 0,872 \\
Item 4_Brand Loy & 0,817 \\
\hline
\end{tabular}




\subsection{Tanggapan Responden Tentang Ekuitas Merek Biskuit Buatan Indonesia Dan Buatan Malaysia}

\subsubsection{Tanggapan Responden Tentang Asosiasi Merek}

Tanggapan responden tentang asosiasi merek buatan Indonesia dikemukakan sebagai berikut :

Tabel 6. Tanggapan Responden Tentang Asosiasi Merek Biskuit Buatan Indonesia

\begin{tabular}{|c|c|c|c|c|c|c|c|c|c|c|}
\hline No & Item Pernyataan & $\begin{array}{l}\text { Tr } \\
\text { SS } \\
(5)\end{array}$ & $\begin{array}{l}\text { ngga } \\
\text { S } \\
(4)\end{array}$ & $\begin{array}{l}\mathbf{P a n} \mathbf{F} \\
\mathbf{N} \\
(3)\end{array}$ & $\begin{array}{c}\text { espol } \\
\text { TS } \\
(2)\end{array}$ & $\begin{array}{l}\text { den } \\
\text { STS } \\
(1) \\
\end{array}$ & $\begin{array}{c}\text { Jml } \\
\text { Resp }\end{array}$ & $\begin{array}{l}\text { Total } \\
\text { Skor }\end{array}$ & $\begin{array}{c}\text { Rata2 } \\
\text { (mean) }\end{array}$ & Interpretasi \\
\hline 1 & $\begin{array}{l}\text { Merek biskuit yang } \\
\text { sudah lama ada di pasar }\end{array}$ & 16 & 32 & 27 & 5 & 0 & 80 & 299 & 3,74 & Tinggi \\
\hline 2 & $\begin{array}{l}\text { Dikenal sebagai merek } \\
\text { biskuit terpercaya }\end{array}$ & 13 & 32 & 31 & 4 & 0 & 80 & 294 & 3,56 & Tinggi \\
\hline 3 & $\begin{array}{l}\text { Unggul Dalam kategori } \\
\text { produk biskuit }\end{array}$ & 8 & 30 & 33 & 8 & 1 & 80 & 280 & 3,50 & Tinggi \\
\hline 4 & Harga sesuai manfaat & 11 & 27 & 32 & 9 & 1 & 80 & 278 & 3,48 & Tinggi \\
\hline 5 & $\begin{array}{l}\text { Lebih banyak diminati } \\
\text { dibandingkan merek } \\
\text { pesaing }\end{array}$ & 0 & 23 & 40 & 16 & 1 & 80 & 245 & 3,06 & Sedang \\
\hline 6 & $\begin{array}{l}\text { Banyak dinikmati } \\
\text { sebagai makanan ringan } \\
\text { yang praktis dikonsumsi }\end{array}$ & 12 & 46 & 18 & 3 & 1 & 80 & 305 & 3,81 & Tinggi \\
\hline 7 & $\begin{array}{l}\text { Banyak dinikmati } \\
\text { sebagai makanan ringan } \\
\text { yang menawarkan variasi } \\
\text { rasa yang nikmat. } \\
\text { Total Skor Variabel } \\
\text { Asosiasi Merek Biskuit } \\
\text { Buatan Indonesia }\end{array}$ & 18 & 29 & 27 & 5 & 1 & 80 & 1999 & $\mathbf{3 , 5 7}$ & Tinggi \\
\hline
\end{tabular}

Secara keseluruhan, tanggapan tentang asosiasi merek pada biskuit buatan Indonesia berada pada level tinggi, kecuali asosiasi bahwa merek biskuit lebih banyak diminati dibandingkan pesaing ditanggapi pada level menengah. Asosiasi merek atas merek biskuit Indonesia paling banyak dikarenakan penilaian bahwa merek biskuit banyak dinikmati sebagai makanan ringan yang praktis dikonsumsi. Sedangkan item yang cenderung paling sedikit berkontribusi pada asosiasi merek adalah tanggapan bahwa merek biskuit lebih banyak diminati dibandingkan pesaing.

Tabel 7 menjelaskan bahwa secara keseluruhan, penilaian responden terhadap asosiasi merek biskuit buatan Malaysia berada pada level menengah. Jika diamati pada setiap item, terdapat 3 item yang dinilai tinggi yaitu unggul dalam kategori produk biskuit, banyak dinikmati sebagai makanan ringan yang praktis dikonsumsi, dan banyak dinikmati sebagai makanan ringan yang menawarkan variasi rasa yang nikmat. Terdapat 4 item yang dinilai moderat yaitu merek biskuit yang sudah lama ada di pasar, dikenal sebagai merek biskuit terpercaya, harga sesuai manfaat, dan lebih banyak diminati . Asosiasi merek sebagai tanggapan responden atas merek Malaysia paling banyak 
dikarenakan oleh keunggulan dalam kategori produk biskuit dan banyak dinikmati sebagai makanan ringan yang praktis dikonsumsi. Sedangkan penilaian asosiasi merek sangat sedikit dikarenakan dikenal sebagai merek biskuit terpercaya.

Tabel 7. Tanggapan Responden Tentang Asosiasi Merek Biskuit Buatan Malaysia

\begin{tabular}{|c|c|c|c|c|c|c|c|c|c|c|}
\hline \multirow[b]{2}{*}{ No } & \multirow[b]{2}{*}{ Item Pernyataan } & \multicolumn{5}{|c|}{ Tanggapan Responden } & \multirow[b]{2}{*}{$\begin{array}{c}\text { Jml } \\
\text { Resp }\end{array}$} & \multirow[b]{2}{*}{$\begin{array}{l}\text { Total } \\
\text { Skor }\end{array}$} & \multirow[b]{2}{*}{$\begin{array}{c}\text { Rata2 } \\
(\text { mean })\end{array}$} & \multirow[b]{2}{*}{ Interpretasi } \\
\hline & & $\begin{array}{l}\text { SS } \\
(5)\end{array}$ & $\begin{array}{l}S \\
(4)\end{array}$ & $\begin{array}{l}\mathbf{N} \\
(3)\end{array}$ & TS & $\begin{array}{l}\text { STS } \\
\text { (1) }\end{array}$ & & & & \\
\hline 1 & $\begin{array}{l}\text { Merek biskuit yang } \\
\text { sudah lama ada di pasar }\end{array}$ & 8 & 20 & 43 & 7 & 2 & 80 & 260 & 3,25 & Sedang \\
\hline 2 & $\begin{array}{l}\text { Dikenal sebagai merek } \\
\text { biskuit terpercaya }\end{array}$ & 2 & 17 & 46 & 13 & 2 & 80 & 243 & 3,04 & Sedang \\
\hline 3 & $\begin{array}{l}\text { Unggul Dalam kategori } \\
\text { produk biskuit }\end{array}$ & 1 & 35 & 39 & 2 & 3 & 80 & 264 & 3,70 & Tinggi \\
\hline 4 & Harga sesuai manfaat & 4 & 16 & 41 & 18 & 1 & 80 & 238 & 2,98 & Sedang \\
\hline 5 & $\begin{array}{l}\text { Lebih banyak diminati } \\
\text { dibandingkan merek } \\
\text { pesaing }\end{array}$ & 0 & 14 & 40 & 24 & 2 & 80 & 224 & 2,80 & Sedang \\
\hline 6 & $\begin{array}{l}\text { Banyak dinikmati } \\
\text { sebagai makanan ringan } \\
\text { yang praktis dikonsumsi }\end{array}$ & 10 & 45 & 17 & 8 & 0 & 80 & 296 & 3,70 & Tinggi \\
\hline 7 & $\begin{array}{l}\text { Banyak dinikmati } \\
\text { sebagai makanan ringan } \\
\text { yang menawarkan variasi } \\
\text { rasa yang nikmat. } \\
\text { Total Skor Variabel } \\
\text { Asosiasi Merek Biskuit } \\
\text { Buatan Malaysia }\end{array}$ & 10 & 34 & 25 & 10 & 1 & 80 & 1812 & 3,24 & Sedang \\
\hline
\end{tabular}

Tabel 8. Tanggapan Responden Tentang Kualitas Yang Dirasakan Biskuit Buatan Indonesia

\begin{tabular}{|c|c|c|c|c|c|c|c|c|c|c|}
\hline No & Item Pernyataan & $\begin{array}{l}\text { Ta } \\
\text { SS } \\
(5)\end{array}$ & $\begin{array}{l}\text { ngga } \\
\text { S } \\
(4)\end{array}$ & $\begin{array}{c}\text { oan I } \\
\text { (3) }\end{array}$ & $\begin{array}{l}\text { espo } \\
\text { TS } \\
(2)\end{array}$ & $\begin{array}{l}\text { den } \\
\text { STS } \\
(1)\end{array}$ & $\begin{array}{c}\text { Jml } \\
\text { Resp }\end{array}$ & $\begin{array}{l}\text { Total } \\
\text { Skor }\end{array}$ & $\begin{array}{c}\text { Rata2 } \\
\text { (mean) }\end{array}$ & Interpretasi \\
\hline 1 & Rasa enak & 21 & 34 & 20 & 5 & 0 & 80 & 311 & 3,89 & Tinggi \\
\hline 2 & $\begin{array}{l}\text { Kandungan bahan aman } \\
\text { dikonsumsi }\end{array}$ & 8 & 43 & 29 & 0 & 0 & 80 & 299 & 3,74 & Tinggi \\
\hline 3 & Disain kemasan menarik & 4 & 39 & 27 & 7 & 3 & 80 & 274 & 3,43 & Tinggi \\
\hline 4 & $\begin{array}{l}\text { Kemasan mampu } \\
\text { melindungi isi }\end{array}$ & 5 & 39 & 30 & 6 & 0 & 80 & 283 & 3,54 & Tinggi \\
\hline 5 & $\begin{array}{l}\text { Informasi komposisi } \\
\text { bahan terlihat jelas pada } \\
\text { kemasan }\end{array}$ & 24 & 33 & 21 & 2 & 0 & 80 & 319 & 3,99 & Tinggi \\
\hline 6 & $\begin{array}{l}\text { Informasi masa kadaluarsa } \\
\text { jelas terlihat } \\
\text { Total Skor Variabel } \\
\text { Kualitas Yang Dirasakan } \\
\text { Biskuit Buatan Indonesia }\end{array}$ & 35 & 33 & 11 & 1 & 0 & 80 & 1828 & 4,28 & $\begin{array}{c}\text { Sangat Tinggi } \\
\text { Tinggi }\end{array}$ \\
\hline
\end{tabular}




\subsubsection{Tanggapan Responden Tentang Kualitas Yang Dirasakan}

Tanggapan responden tentang loyalitas merek buatan Indonesia dikemukakan pada Tabel 8. Secara keseluruhan, kualitas yang dirasakan responden pada biskuit merek Indonesia berada pada level tinggi. Demikian pula tanggapan pada setiap item kualitas yang dirasakan, semuanya menunjukkan respon yang tinggi, kecuali item Informasi masa kadaluarsa jelas terlihat dinilai sangat tinggi. Kualitas yang dirasakan atas merek biskuit Indonesia paling banyak dikarenakan kejelasan informasi tentang masa kadaluarsa. Sedangkan item yang cenderung paling sedikit berkontribusi pada kualitas yang dirasakan adalah dalam hal daya tarik disain kemasan.

Berikut dikemukakan tanggapan kualitas yang dirasakan responden untuk merek biskuit buatan Malaysia.

Tabel 9. Tanggapan Responden Tentang Kualitas Yang Dirasakan Biskuit Buatan Malaysia

\begin{tabular}{|c|c|c|c|c|c|c|c|c|c|c|}
\hline \multirow[b]{2}{*}{ No } & \multirow[b]{2}{*}{ Item Pernyataan } & \multicolumn{5}{|c|}{ Tanggapan Responden } & \multirow[b]{2}{*}{$\begin{array}{l}\text { Jml } \\
\text { Resp }\end{array}$} & \multirow[b]{2}{*}{$\begin{array}{l}\text { Total } \\
\text { Skor }\end{array}$} & \multirow[b]{2}{*}{$\begin{array}{l}\text { Rata2 } \\
\text { (mean) }\end{array}$} & \multirow[b]{2}{*}{ Interpretas } \\
\hline & & $\begin{array}{l}\text { SS } \\
(5)\end{array}$ & $\begin{array}{l}\mathrm{S} \\
(4)\end{array}$ & $\begin{array}{l}\mathrm{N} \\
(3)\end{array}$ & $\begin{array}{l}\mathrm{TS} \\
(2)\end{array}$ & $\begin{array}{l}\text { STS } \\
(1)\end{array}$ & & & & \\
\hline 1 & Rasa enak & 19 & 45 & 13 & 2 & 1 & 80 & 319 & 3,99 & Tinggi \\
\hline 2 & $\begin{array}{l}\text { Kandungan bahan aman } \\
\text { dikonsumsi }\end{array}$ & 6 & 43 & 28 & 3 & 0 & 80 & 292 & 3,65 & Tinggi \\
\hline 3 & Disain kemasan menarik & 12 & 39 & 16 & 13 & 0 & 80 & 290 & 3,63 & Tinggi \\
\hline 4 & $\begin{array}{l}\text { Kemasan mampu melindungi } \\
\text { isi }\end{array}$ & 9 & 41 & 23 & 5 & 2 & 80 & 290 & 3,63 & Tinggi \\
\hline 5 & $\begin{array}{l}\text { Informasi komposisi bahan } \\
\text { terlihat jelas pada kemasan }\end{array}$ & 18 & 43 & 11 & 8 & 0 & 80 & 311 & 3,89 & Tinggi \\
\hline 6 & $\begin{array}{l}\text { Informasi masa kadaluarsa } \\
\text { jelas terlihat }\end{array}$ & 18 & 44 & 12 & 5 & 1 & 80 & 313 & 3,91 & Tinggi \\
\hline & $\begin{array}{l}\text { Total Skor Variabel } \\
\text { Kualitas Yang Dirasakan } \\
\text { Biskuit Buatan Malavsia }\end{array}$ & & & & & & 80 & 1815 & 3,78 & Tinggi \\
\hline
\end{tabular}

Tabel 9 menginformasikan bahwa secara keseluruhan, kualitas yang dirasakan responden terhadap merek biskuit buatan Malaysia berada pada level tinggi. Demikian pula tanggapan pada setiap item kualitas yang dirasakan, semuanya menunjukkan respon yang tinggi. Kualitas yang dirasakan responden merek Malaysia paling banyak dikarenakan oleh rasanya yang enak, dan sangat sedikit dikarenakan disain kemasan menarik. Dengan demikian terdapat persamaan tanggapan mengenai kualitas yang dirasakan antara merek biskuit buatan Indonesia dan Malaysia yaitu bahwa daya tarik disain kemasan masih belum memadai.

\subsubsection{Tanggapan Responden Tentang Loyalitas Merek}

Tanggapan responden tentang loyalitas merek buatan Indonesia dikemukakan sebagai berikut : 
Tabel 10. Tanggapan Responden Tentang Loyalitas Merek Biskuit Buatan Indonesia

\begin{tabular}{|c|c|c|c|c|c|c|c|c|c|c|}
\hline \multirow[b]{2}{*}{ No } & \multirow[b]{2}{*}{ Item Pernyataan } & \multicolumn{5}{|c|}{ Tanggapan Responden } & \multirow[b]{2}{*}{$\begin{array}{c}\text { Jml } \\
\text { Resp }\end{array}$} & \multirow[b]{2}{*}{$\begin{array}{l}\text { Total } \\
\text { Skor }\end{array}$} & \multirow[b]{2}{*}{$\begin{array}{l}\text { Rata2 } \\
\text { (mean) }\end{array}$} & \multirow[b]{2}{*}{ Interpretasi } \\
\hline & & $\begin{array}{l}\text { SS } \\
(5)\end{array}$ & $\begin{array}{l}S \\
(4)\end{array}$ & $\begin{array}{l}\mathbf{N} \\
(3)\end{array}$ & $\begin{array}{l}\text { TS } \\
(2)\end{array}$ & $\begin{array}{l}\text { STS } \\
(1)\end{array}$ & & & & \\
\hline 1 & Memprioritaskan pilihan & 4 & 25 & 42 & 5 & 4 & 80 & 260 & 3,25 & Sedang \\
\hline 2 & $\begin{array}{l}\text { Menceritakan hal-hal } \\
\text { positif kepada orang lain }\end{array}$ & 5 & 10 & 40 & 24 & 1 & 80 & 233 & 2,91 & Sedang \\
\hline 3 & $\begin{array}{l}\text { Merekomendasikan pada } \\
\text { orang lain }\end{array}$ & 5 & 28 & 34 & 11 & 2 & 80 & 262 & 3,28 & Sedang \\
\hline 4 & $\begin{array}{l}\text { Tetap membeli walaupun } \\
\text { harga lebih tinggi }\end{array}$ & 3 & 22 & 35 & 16 & 4 & 80 & 243 & 3,04 & Sedang \\
\hline & $\begin{array}{l}\text { Total Skor Variabel } \\
\text { Loyalitas Merek } \\
\text { Biskuit Biatan } \\
\text { Indonesia }\end{array}$ & & & & & & & 998 & 3,12 & Sedang \\
\hline
\end{tabular}

Secara keseluruhan, loyalitas responden pada biskuit merek Indonesia berada pada level sedang. Demikian pula tanggapan pada setiap item loyalitas, semuanya menunjukkan respon yang sedang, baik dalam hal prioritas pilihan, word of mouth positif, rekomendasi pada orang lain dan kesediaan membeli jika harga lebih tinggi dari pesaing. Loyalitas merek cenderung banyak dikarenakan oleh perilaku yang memprioritaskan pilihan pada biskuit Indonesia di waktu mendatang, sedangkan perilaku word of mouth positif cenderung yang paling sedikit berkontribusi pada loyalitas responden.Berikut dikemukakan tanggapan loyalitas responden untuk merk biskuit buatan Malaysia.

Tabel 11. Tanggapan Responden Tentang Loyalitas Merek Biskuit Buatan Malaysia

\begin{tabular}{|c|c|c|c|c|c|c|c|c|c|c|}
\hline \multirow[b]{2}{*}{ No } & \multirow[b]{2}{*}{ Item Pernyataan } & \multicolumn{5}{|c|}{ Tanggapan Responden } & \multirow[b]{2}{*}{$\begin{array}{l}\text { Jml } \\
\text { Resp }\end{array}$} & \multirow[b]{2}{*}{$\begin{array}{l}\text { Total } \\
\text { Skor }\end{array}$} & \multirow[b]{2}{*}{$\begin{array}{l}\text { Rata2 } \\
\text { (mean) }\end{array}$} & \multirow[b]{2}{*}{ Interpretasi } \\
\hline & & $\begin{array}{l}\text { SS } \\
(5)\end{array}$ & S & $\begin{array}{l}\mathrm{N} \\
(3)\end{array}$ & $\begin{array}{l}\text { TS } \\
(2)\end{array}$ & $\begin{array}{l}\text { STS } \\
\text { (1) }\end{array}$ & & & & \\
\hline 1 & $\begin{array}{l}\text { Memprioritaskan } \\
\text { pilihan }\end{array}$ & 2 & 11 & 45 & 17 & 5 & 80 & 227 & 2,84 & Sedang \\
\hline 2 & $\begin{array}{l}\text { Menceritakan hal-hal } \\
\text { positif kepada orang } \\
\text { lain }\end{array}$ & 0 & 11 & 43 & 15 & 11 & 80 & 213 & 2,66 & Sedang \\
\hline 3 & $\begin{array}{l}\text { Merekomendasikan } \\
\text { pada orang lain }\end{array}$ & 0 & 19 & 37 & 16 & 8 & 80 & 227 & 2,84 & Sedang \\
\hline \multirow[t]{2}{*}{4} & $\begin{array}{l}\text { Tetap membeli } \\
\text { walaupun harga } \\
\text { lebih tinggi }\end{array}$ & 1 & 9 & 35 & 26 & 9 & 80 & 207 & 2,59 & Rendah \\
\hline & $\begin{array}{l}\text { Total Skor Variabel } \\
\text { Loyalitas Merek } \\
\text { Biskuit Buatan } \\
\text { Malaysia }\end{array}$ & & & & & & 80 & 874 & 2,73 & Sedang \\
\hline
\end{tabular}

Tabel 11 menjelaskan bahwa secara keseluruhan, loyalitas responden pada biskuit merek Malaysia berada pada level sedang. Demikian pula tanggapan pada setiap item loyalitas, semuanya menunjukkan respon yang sedang, kecuali pada item tetap membeli walaupun harga lebih tinggi dari pesaing. Loyalitas merek responden paling banyak 
dikarenakan oleh perilaku yang memprioritaskan pilihan pada biskuit Malaysia di waktu mendatang dan merekomendasikan pada orang lain. Loyalitas merek responden sangat sedikit dikarenakan menerima kenaikan harga. Hal ini menunjukkan bahwa kecendrungan responden yang memiliki kepekaan yang tinggi terhadap harga.

\subsection{Tanggapan Responden Tentang Ekuitas Merek}

Tanggapan responden tentang ekuitas merek meliputi penilaian terhadap ingatan responden tentang merek yang merupakan asosiasi mereka atas merek biskuit yang dikonsumsi, kualitas yang dirasakan responden atas merek biskuit tersebut dan loyalitas responden terhadap merek biskuit. Tabel 12 dan Tabel 13 berikut ini dikemukakan tanggapan responden terhadap ekuitas merek biskuit buatan Indonesia dengan buatan Malaysia.

Tabel 12. Tanggapan Responden Tentang Ekuitas Merek Biskuit Buatan Indonesia

\begin{tabular}{llcccc}
\hline No & \multicolumn{1}{c}{ Item Pernyataan } & $\begin{array}{c}\text { Jml } \\
\text { Resp }\end{array}$ & $\begin{array}{c}\text { Total } \\
\text { Skor }\end{array}$ & $\begin{array}{c}\text { Rata2 } \\
(\text { mean })\end{array}$ & Interpretasi \\
\hline 1 & Asosiasi Merek & 80 & 1999 & 3,57 & Tinggi \\
2 & Kualitas Yang Dirasakan & 80 & 1828 & 3,81 & Tinggi \\
3 & Loyalitas Merek & 80 & 998 & 3,12 & Sedang \\
& $\begin{array}{l}\text { Total Skor Variabel Ekuitas } \\
\text { Merek Biskuit Biatan }\end{array}$ & 80 & 4825 & 4,71 & Sangat \\
$\quad$ Indonesia & & & & Tinggi \\
\hline
\end{tabular}

Informasi dari Tabel 12 tampak bahwa ekuitas merek biskuit buatan Indonesia berada pada level sangat tinggi. Dimensi yang paling memberi kontribusi pada ekuitas merek berturut-turut dari yang paling besar adalah kualitas yang dirasakan, asosiasi merek dan yang paling kecil adalah loyalitas merek. Ini menunjukkan bahwa loyalitas merek cenderung sulit diandalkan dalam pembentuakan ekuitas merek pada merek- merek produk biskuit buatan Indonesia yang diamati.

Tabel 13. Tanggapan Responden Tentang Ekuitas Merek Biskuit Buatan Malaysia

\begin{tabular}{llcccc}
\hline No & \multicolumn{1}{c}{ Item Pernyataan } & $\begin{array}{c}\text { Jml } \\
\text { Resp }\end{array}$ & $\begin{array}{c}\text { Total } \\
\text { Skor }\end{array}$ & $\begin{array}{c}\text { Rata2 } \\
\text { (mean) }\end{array}$ & Interpretasi \\
\hline 1 & Asosiasi Merek & 80 & 1812 & 3,24 & Sedang \\
2 & Kualitas Yang Dirasakan & 80 & 1815 & 3,78 & Tinggi \\
3 & Loyalitas Merek & 80 & 874 & 2,73 & Sedang \\
& $\begin{array}{l}\text { Total Skor Variabel Ekuitas } \\
\quad \text { Merek Biskuit Buatan }\end{array}$ & 80 & 4501 & 3,31 & Sedang \\
$\quad$ Malaysia & & & & \\
\hline
\end{tabular}

Informasi pada Tabel 13 tampak bahwa ekuitas merek biskuit buatan Malaysia berada pada level menengah. Dimensi yang paling memberi kontribusi pada ekuitas 
merek berturut-turut dari yang paling besar adalah kualitas yang dirasakan, loyalitas merek dan yang paling kecil adalah asosiasi merek. Ini menunjukkan bahwa asosiasi merek cenderung sulit diandalkan dalam pembentuakan ekuitas merek pada merek- merek produk biskuit buatan Malaysia yang diamati.

Berdasarkan Tabel 12 dan Tabel 13 tampak bahwa terdapat perbedaan tanggapan antara merek biskuit buatanIndonesia dengan buatan Malaysia, dimana ekuitas merek pada biskuit buatan Indonesia cenderung dinilai lebih tinggi. Penilaian yang lebih tinggi terhadap merek biskuit buatan Indonesia ini terhjadi baik pada ekuitas merek secara keseluruhan maupun pada setiap dimensi ekuitas merek yaitu asosiasi merek, kualitas yang dirasakan dan loyalitas merek.

\subsection{Uji Beda Ekuitas Merek Biskuit Buatan Indonesia Dengan Biskuit Buatan Buatan Malaysia.}

Untuk mengetahui bagaimana perbedaan diantara merek merek biskuit buatan Indonesia yang diamati yaitu Roma, Khong Guan, Dane's dan Unibis dilakukan pengujian dengan metode One Way Anova. Hasil uji beda ini ditunjukkan pada Tabel 14.

Tabel 14. Uji Beda Diantara Merek Biskuit Buatan Indonesia

\begin{tabular}{|c|c|c|c|c|c|c|}
\hline \multicolumn{7}{|c|}{ ANOVA } \\
\hline & & Sum of Squares & df & Mean Square & $\mathrm{F}$ & Sig. \\
\hline \multirow[t]{3}{*}{ B_ASS } & Between Groups & 881.250 & 3 & 293.750 & 18.851 & .000 \\
\hline & Within Groups & 1184.300 & 76 & 15.583 & & \\
\hline & Total & 2065.550 & 79 & & & \\
\hline \multirow[t]{3}{*}{ PQ } & Between Groups & 281.538 & 3 & 93.846 & 12.075 & .000 \\
\hline & Within Groups & 590.650 & 76 & 7.772 & & \\
\hline & Total & 872.188 & 79 & & & \\
\hline \multirow[t]{3}{*}{ B_LOY } & Between Groups & 191.700 & 3 & 63.900 & 7.258 & .000 \\
\hline & Within Groups & 669.100 & 76 & 8.804 & & \\
\hline & Total & 860.800 & 79 & & & \\
\hline \multirow[t]{3}{*}{$\mathrm{BE}$} & Between Groups & 3521.737 & 3 & 1173.912 & 17.946 & .000 \\
\hline & Within Groups & 4971.450 & 76 & 65.414 & & \\
\hline & Total & 8493.187 & 79 & & & \\
\hline
\end{tabular}

Dari Tabel 14 di atas dapat dijelaskan bahwa terdapat perbedaan yang signifikan diantara merek biskuit buatan Indonesia yang diamati dalam penelitian ini yaitu merek Roma, Khong Guan, Dane's dan Unibis, baik dalam hal asosiasi merek, kualitas yang dirasakan, loyalitas merek dan ekuitas merek. Untuk selanjutnya akan dilihat merek merek apa saja yang berbeda dan merek apa saja yang sama.

Hal ini dapat diketahui dengan malakukan test Turkey, yang hasilnya adalah sebagai berikut : 


\section{Tabel 15. Persamaan Dan Perbedaan Diantara Merek Buatan Indonesia}

\begin{tabular}{cccc}
\hline Perbedaan Antar Merek & Sig. & Kriteria uji Turkey & Kesimpulan \\
Roma dengan Khong Guan & 0,604 & $>0,05$ & Tidak berbeda \\
Roma dengan Dane's & 0,000 & $<0,05$ & Berbeda \\
Roma dengan Unibis & 0,000 & $<0,05$ & Berbeda \\
Khong Guan dengan Dane's & 0,000 & $<0,05$ & Berbeda \\
Khong Guan dengan Unibis & 0,002 & $<0,05$ & Berbeda \\
Dane's dengan Unibis & 0,406 & $>0,05$ & Tidak berbeda \\
\hline
\end{tabular}

Tabel 15 menginformasikan bahwa persamaan terdapat pada merek Khong Guan dan Roma , lalu Dane's dan Unibis. Sedangkan antara Roma dan Khong Guan dengan Dane's dan Unibis terdapat perbedaan. Hal ini sesuai pada kenyataannya dimana antara Khong Guan dengan Roma dan Dane's dengan Unibis memiliki banyak persamaan diantaranya dalam hal variasi rasa, kemasan dan rentang harga.

Selanjutnya akan dilihat bagaimana perbedaan diantara merek biskuit buatan Malaysia. Apakah diantara merek biskuit buatan Malaysia yang diamati terdapat perbedaan yang signifikan atau tidak. Pengujian ini dilakukan dengan menggunakan metode One Way Anova, yang hasilnya adalah sebagai berikut :

Tabel 16. Uji Beda Diantara Merek Biskuit Buatan Malaysia

\begin{tabular}{|c|c|c|c|c|c|c|}
\hline \multicolumn{7}{|c|}{ ANOVA } \\
\hline & & Sum of Squares & $\mathrm{df}$ & Mean Square & $\mathrm{F}$ & Sig. \\
\hline \multirow[t]{3}{*}{ B_ASS } & Between Groups & 18.700 & 3 & 6.233 & .422 & .737 \\
\hline & Within Groups & 1121.500 & 76 & 14.757 & & \\
\hline & Total & 1140.200 & 79 & & & \\
\hline \multirow[t]{3}{*}{ PQ } & Between Groups & 60.338 & 3 & 20.112 & 2.004 & .121 \\
\hline & Within Groups & 762.850 & 76 & 10.038 & & \\
\hline & Total & 823.188 & 79 & & & \\
\hline \multirow[t]{3}{*}{ B_LOY } & Between Groups & 18.450 & 3 & 6.150 & .821 & .486 \\
\hline & Within Groups & 569.100 & 76 & 7.488 & & \\
\hline & Total & 587.550 & 79 & & & \\
\hline \multirow[t]{3}{*}{ B_EQUITY } & Between Groups & 143.138 & 3 & 47.713 & .804 & .496 \\
\hline & Within Groups & 4510.350 & 76 & 59.347 & & \\
\hline & Total & 4653.488 & 79 & & & \\
\hline
\end{tabular}

Tabel 16 menjelaskan bahwa tidak terdapat perbedaan yang signifikan diantara merek biskuit buatan Malaysia yang diamati dalam penelitian ini yaitu merek Munchy's, Pimpong, Shoon Fat dan Hup Seng, baik dalam hal asosiasi merek, kualitas yang dirasakan, loyalitas merek dan ekuitas merek. Hal ini dapat menjelaskan keadaan dimana merek biskuit buatan Malaysia yang diamati dalam penelitian ini memiliki fitur produk yang cenderung memiliki persamaan terutama dalam hal kemasan, ukuran, pelabelan, 
variasi rasa, dan rentang harga. Persamaan ini menunjukkan bahwa atribut produk biskuit buatan Malaysia memiliki standart kualitas yang cenderung serupa.

Selanjutnya akan dilihat bagaimana perbedaan diantara merek biskuit buatan Indonesia dengan merek biskuit buatan Malaysia.

Tabel 17. Uji Beda Diantara Merek Biskuit Buatan Indonesia Dan Buatan Malaysia

\begin{tabular}{llrrrrr}
\hline \multirow{4}{*}{ B_ASS } & & ANOVA & & & & Sig. \\
& Between Groups & Sum of Squares & df & Mean Square & F & .001 \\
& Within Groups & 235.225 & 1 & 235.225 & 11.593 & \\
P_QUALITY & Total & 3205.750 & 158 & 20.290 & & .810 \\
& Between Groups & 3440.975 & 159 & & & \\
& Within Groups & .625 & 1 & .625 & .058 & \\
B_LOY & Total & 1695.375 & 158 & 10.730 & & .000 \\
& Between Groups & 1696.000 & 159 & & & \\
& Within Groups & 140.625 & 1 & 140.625 & 15.341 \\
B_EQUITY & Total & 1448.350 & 158 & 9.167 & & \\
& Between Groups & 1588.975 & 159 & & & \\
& Within Groups & 783.225 & 1 & 783.225 & 9.413 \\
& Total & 13146.675 & 158 & 83.207 & & \\
\hline
\end{tabular}

Tabel 17 menginformasikan bahwa diantara merek biskuit buatan Indonesia dengan buatan Malaysia terdapat perbedaan dalam hal asosiasi merek, loyalitas merek dan ekuitas merek. Sedangkan persamaan diantara kedunya terdapat pada kualitas yang dirasakan. Berikut akan dijelaskan lebih lanjut terhadap perbedaan tersebut.

Tabel 18. Perbedaan Tanggapan

\begin{tabular}{lcccc}
\hline \multirow{2}{*}{ Tanggapan Responden } & \multicolumn{2}{c}{ Merek Biskuit Buatan Indomesia } & \multicolumn{2}{c}{ Merek Biskuit Buatan Malaysia } \\
\cline { 2 - 5 } & Rata-Rata & Interpretasi & Rata-Rata & Interpretasi \\
\hline Asosiasi Merek & 3,57 & Tinggi & 3,24 & Sedang \\
Kualitas Yang Dirasakan & 3,81 & Tinggi & 3,78 & Tinggi \\
Loyalitas Merek & 3,12 & Sedang & 2,73 & Sedang \\
Ekuitas Merek & 4,71 & Sangat Tinggi & 3,31 & Sedang \\
\hline
\end{tabular}

Tabel 18 menginfomasikan nilai rata-rata tanggapan responden beserta interpretasi terhadap merek biskuit buatan Indonesia dengan buatan Malaysia. Terdapat perbedaan tanggapan dalam hal asosiasi merek, loyalitas merk dan ekuitas merek keseluruhan, dimana rata-rata tanggapan responden terhadap merek biskuit buatan Indonesia dinilai lebih tinggi daripada biskuit buatan Malaysia. Hal ini menunjukkan bahwa responden penelitian ini memberikan penilaian yang positif terhadap merek biskuit buatan dalam negeri. Karakteristik responden yang umumnya masih berusia muda dan pendapatan responden yang sebagian besar berada di level menengah dan bawah, mendorong mereka 
untuk menjadikan merek biskuit buatan dalam negeri sebagai merek yang paling dekat dengan mereka dan menjadikannya prioritas untuk dibeli. Apalagi harga biskuit dalam negeri yang dirasakan lebih sesuai dengan daya beli mereka sehingga membuat mereka lebih loyal. Hal ini terjadi dikarenakan responden merupakan pembeli yang relatif peka terhadap harga. Temuan penelitian ini mendukung temuan penelitian oleh Jung dan Sung (2008) yang menjelaskan bahwa tanggapan asosiasi merek dan loyalitas merek pada merek lokal Amerika lebih tinggi dari pada merek impor Korea Selatan. Sebaliknya, hasil penelitian ini menolak penelitian oleh Liaogang et al (2007) bahwa merek asing ditanggapi lebih baik dibandingkan merek lokal.

Berbeda halnya dengan tanggapan mengenai kualitas yang dirasakan. Hasil uji beda menunjukkan tidak terdapat perbedaan yang signifikan antara kualitas yang diraskan dari merek biskuit Indonesia dengan merek biskuit Malaysia. Responden dalam penelitian ini tidak merasakan adanya perbedaan yang mencolok dalam kandungan bahan, kemasan, informasi bahan yang digunakan dan informasi tentang masa kadaluarsa. Hal ini sangat dimungkinkan mengingat responden kebanyakan memiliki tingkat pendidikan pada level menengah, sehingga kualitas yang dirasakan yang menjadi unsur pembeda utama adalah faktor "rasa" saja, tidak secara mendalam memperhatikan aspek kemasan, komposisi bahan dan masa kadaluarsa. Atribut ini dianggap sama saja diantara merek-merek biskuit yang dijual di pasar.

\section{KESIMPULAN}

Berdasarkan uraian pembahasan yang telah dikemukakan, dapat disimpulkan beberapa hal berikut :

1. Ekuitas merek biskuit buatan Indonesia berada pada level sangat tinggi. Dimensi yang paling memberi kontribusi pada ekuitas merek berturut-turut dari yang paling besar adalah kualitas yang dirasakan, asosiasi merek dan yang paling kecil adalah loyalitas merek. Ini menunjukkan bahwa loyalitas merek cenderung sulit diandalkan dalam pembentuakan ekuitas merek pada merek- merek produk biskuit buatan Indonesia yang diamati.

2. Ekuitas merek biskuit buatan Malaysia berada pada level menengah. Dimensi yang paling memberi kontribusi pada ekuitas merek berturut-turut dari yang paling besar adalah kualitas yang dirasakan, loyalitas merek dan yang paling kecil adalah asosiasi merek. Ini menunjukkan bahwa asosiasi merek cenderung sulit diandalkan dalam pembentukan ekuitas merek pada merek - merek produk biskuit buatan Malaysia yang diamati.

3. Terdapat perbedaan yang signifikan diantara merek biskuit buatan Indonesia yang diamati dalam penelitian ini yaitu merek Roma, Khong Guan, Dane's dan Unibis, baik dalam hal asosiasi merek, kualitas yang dirasakan, loyalitas merek dan ekuitas merek keseluruhan. Hal ini sesuai pada kenyataannya dimana antara Khong Guan dan Roma 
kemudian Dane's dan Unibis memiliki banyak persamaan diantaranya dalam hal variasi rasa, kemasan dan rentang harga.

4. Tidak terdapat perbedaan yang signifikan diantara merek biskuit buatan Malaysia yang diamati dalam penelitian ini yaitu merek Munchy's, Pimpong, Shoon Fat dan Hup Seng, baik dalam hal asosiasi merek, kualitas yang dirasakan, loyalitas merek dan ekuitas merek secara keseluruhan. Hal ini dapat menjelaskan keadaan dimana merek biskuit buatan Malaysia yang diamati dalam penelitian ini memiliki fitur produk yang cenderung memiliki persamaan terutama dalam hal kemasan, ukuran, pelabelan, variasi rasa, dan rentang harga.

5. Diantara merek biskuit buatan Indonesia dengan buatan Malaysia terdapat perbedaan dalam hal asosiasi merek, loyalitas merek dan ekuitas merek keseluruhan. Sedangkan persamaan diantara keduanya terdapat pada kualitas yang dirasakan.

\section{DAFTAR PUSTAKA}

Aaker, D. A. (1991). Managing brand equity: Capitualizing On The Value Of A Brand Name. New York: The Free Press.

Aaker, D. A. (1996). Measuring Brand Equity Across Products and Markets. New York, NY: The Free Press.

Chen, C. (2001). Using free association to examine the relationship between the characteristics of brand associations and brand equity. The Journal of Product and Brand Management, 10(6/7), 439-451.

Jung, J. \& Sung. E. (2008). Consumer based brand equity: Comparisons among americans and south koreans in the USA and south koreans in Korea. Journal of Pashion Marketing and Management, 12(1), 24-35

Keller, K. L. (1993). Conceptualizing, measuring and managing customer based brand equity. Journal of Marketing, 57(1), 1-22.

Keller, K. L. (2008). Strategic brand management : Building, measuring, and managing brand equity ( $3^{\text {rd }}$ ed.). New Jersey: Pearson Education Inc.

Kotler, P. \& Keller, K. L. (2012). Marketing Management (13 ${ }^{\text {th }}$ ed.). New Jersey: Pearson Education Inc.

Liaogang, H., Chongyan, G. \& Lin Zi A. (2007). Consumer based brand equity and improvement strategy for mobile phone brands : Foreign versus local in the chinese market. International Management Review, 3(3), 76-83

Maholtra, N. K. (2004). Marketing Research : An Applied Orientation (4 ${ }^{\text {th }}$ ed.). New Jersey: Pearson Education Inc.

Mowen, J. C., \& Minor, M. (2001). Consumer Behaviour. Harcourt Inc. 
Peter, J. P., \& Olson, J. C. (1999). Consumer Behavior: Perilaku Konsumen dan Strategi Pemasaran. Jakarta: Penerbit Erlangga

Sekaran, U., (2003). Research Methods For Business. West Sussex: John Willey and Son Inc.

Zhou, L., Yang, Z., \& Hui, M. K. (2010). Non Local Or Local Brand? A Multi Level Investigation Into Confidence In Brand Origin Identification and Its Strategic Implication. Journal Of the Academy Of Marketing Science, 38, 202-218 